\title{
A Retrospective Study on Transitions and Transitional Objects
}

\author{
Sanja Tatalović Vorkapić \\ University of Rijeka \\ sanjatv@uniri.hr
}

Since contemporary studies have clearly provided evidence of a significant impact of kindergarten teachers' early childhood experiences on their work with children, it is important to continuously explore them. Some of these experiences are related to various childhood transitions, adjustments in nursery or kindergarten, and the role and use of transitional objects during childhood. Therefore, the aim of this study was to explore early childhood educators' perception of their personal transitions and transitional objects during childhood. The perception of personal transition periods was examined through a survey created for the purpose of this research, and the retrospective method was used on a sample of 287 educators from Croatia. The prevalence of positive experiences of personal childhood transitions was determined. Soft toys as the most common transitional objects are reported. The findings in this study indicate the significance of studying the process of transition and the role of transitional objects.

Keywords: early childhood teachers, retrospective, students, transition, transitional objects

\section{Introduction}

Adults, both parents in the family context and educators, have an important influence on children of early and (pre) school age entering kindergartens or primary schools (Pianta and Cox 1999; Rimm-Kaufman and Pianta 2000; Tatalović Vorkapić 2000). Such entry is marked by an adjustment process that is crucial, both for the current successful adaptation to the new environment and for the long-term development of integrative psychological skills that significantly affect all further experiences and relationships in the future of the child. The significance of early transition experiences is twofold: it affects a child's current well-being as well as his or her well-being in later life (BenArieh et al. 2014). In addition to the characteristics of the child, the key aspects of the quality transition are actions of parents, educators and teachers, which are often, in addition to existing competencies, 'coloured' by their different outcomes of experiential learning (Tatalović Vorkapić 2019a; 2019b; 2019c; Tatalović Vorkapić and LoCasale-Crouch 2021). 
In addition to the basic pedagogical, psychological and methodical competencies of early childhood educators, it is important to emphasize that their educational practice is not only influenced by what they know but also what they are (Tatalović Vorkapić 2012). It is therefore important to focus on the influence of their attitudes, values, lifestyles and personality traits. More precisely, implicit practices and a hidden curriculum imply awareness of such influences in working with children, which the educator presents in the form of life experiences and attitudes (Tatalović Vorkapić and Knapić 2015). Thus it is understandable that attitudes formed throughout their whole life dominate in the work of educators over competencies, which were adopted during their three-year initial education. Particularly important for quality educational practice are those attitudes and experiences that emerged during intense and challenging periods of life, making them significantly more resistant to change.

This research therefore focuses on the educators' experiences related to their transitions during childhood, as well as on the transitional objects they had. In the same way that we are aware of individual differences amongst children we should be aware of individual differences amongst educators. We have to look at the differences that affect their educational practice both in general periods and in periods of transition and adjustment. In addition, this retrospective study will provide insight into personal experiences of transitions and transitional objects since there has been very little scientific research on this topic, both in Croatia and worldwide.

\section{Childhood Transitions and Transitional Objects}

Having in mind the definition of transition as: 'The process of change that is experienced when children (and their families) move from one setting to another ... to when the child is more fully established as a member of the new setting. It is usually a time of intense and accelerated development demands that are socially regulated' (Fabian and Dunlop 2002, 3), it is understandable that transitions are very challenging and potentially stressful life periods for many children and their families. It is therefore extremely important to take into account all significant aspects of the transition during childhood in order to provide adequate support to children and their families. In order to better understand all the individual aspects, as well as the transition process itself, well-known researchers in this field have developed several significant theoretical models. Thus, Rimm-Kaufman and Pianta (2000) have described four models of possible influences during childhood transitions. The first theoretical model focuses on the characteristics of the child as 
a primary factor in understanding its transition period. The second theoretical model, the model of direct effects in understanding a child's transition, also takes into account the important role of the social context. Furthermore, the third theoretical model, the model of indirect effects, focuses on interactions between social contexts, their connections and interactions. Finally, the fourth and most recent theoretical model, called the Ecological and Dynamic Model of Transition, emphasizes the importance of children's direct and indirect influences, as well as interactions between social contexts, and, unlike the first three models, focuses on understanding the possibility of change in all relationships over time. Like Bronfenbrenner's model of ecosystems (1979), which is the forerunner of the modern ecological-dynamic model of transition, this model of transition also places the child at the centre of changes within his micro environment or family, and within the macro environment consisting of peers, educators, and society. Both internal and external factors significantly affect the quality of the child's transition outcomes during childhood. During the transition, the child goes through a process of adjustment regarding the new space, institution, and situation, surrounded by new and unknown people and children. Contemporary research emphasizes the crucial importance of kindergarten characteristics, organization in providing support to children and families during transition and adjustment, professional (competencies) and personal characteristics of educators (attitudes, personality traits, personal experiences) (Tatalović Vorkapić and Katić 2019a; 2019b).

Therefore, the duration of the adjustment in the new situation during the transition is conditioned by a number of different factors. During this period, the child may show some unusual behaviours, but they are usually transient precisely because the child loses his identity in a new situation while experiencing difficulty finding a new identity or a new role, and thus tries to express his frustration and dissatisfaction. These behaviours are often acting-out behaviours and are manifested through crying, shouting, protesting, anger, refusing contact with educators, diving to the floor, withdrawing from others with their transitional object (pacifier, soft toy, blanket, etc.), aggression and the like. In addition to emotional reactions, children can experience strong somatic reactions such as vomiting, abdominal pain or headaches (Mašković et al. 2018). Thus the educator is the key person who will provide support and assistance to the child in mastering the adjustment in the nursery/kindergarten in a way that will provide a safe environment and an atmosphere of trust (Mihić 2016). These reactions are common in the adaptation process, and it should be borne in mind that they are in most cases transient. 
Moreover, the completion of adaptation is considered the period when the child begins to spontaneously express their feelings, abilities and thoughts, interacts with their environment, and expresses positive emotions.

\section{Transitional Objects}

Transition is closely related to transitional objects defined as: 'An object, typically a soft toy, chosen by an infant or child. Irreplaceable, the object is imbued with the child's feelings for and experience of his or her primary caretaker. The child uses the transitional object to aid the transition from primary dependence to independence' (Wilson and Robinson 2002, 861). The British paediatrician and psychoanalyst Winnicott (1953) has devoted his research work to transitions and transitional objects. He established that children have a strong need for the possession of a certain object, especially during separation from their caregiver. In that way this transitional object has a symbolic role in achieving the continuity of closeness to the parent during challenging situations of separation. Those objects are mostly soft toys such as teddies or similar toys, or blankets or other soft materials that keep a familiar smell to a child and provide a great deal of comfort.

According to Winnicott, the transitional object starts 'each human being off with what will always be important for them: a neutral area of experience which will not be challenged' (Wilson and Robinson 2002, 862). Thus it presents the bridge between an objective and a subjective reality with the continuous tendency to be closer to the objective reality each time the child confronts some frustration or stressful information. The objects play a significant role in the psychological development and well-being of children, with the purpose of facilitating the individuation process by substituting for the primary caregiver and easing the separation within the developmental period of autonomy and its conflict with child dependency (Mahler 1972). It is important to emphasize the significance of the of transitional objects regarding their long-term effect on adolescents' mental health and wellbeing. The study carried out by Bachar and colleagues (1998) has revealed that those participants who reported a frequent use of transitional objects and a high level of attachment also showed more optimal maternal bonding and a higher level of well-being.

Furthermore, cross-cultural studies revealed that there are significant differences in the frequency of attachment to inanimate objects among young children, which depends upon the amount of physical contact with the caregiver, sleeping arrangements and the time spent in childcare facilities. Thus the frequency of use of transitional objects was lower in those who spent 
more time with their caregivers during the day, sharing a bed and having more physical contact with them (Fortuna et al. 2014). However, there is a small number of objective and valid research studies in the field of transitional objects, which resulted in the lack of an integrative theory of attachment to transitional objects during childhood.

\section{The Retrospective Research Study Method}

In this research, a retrospective method was applied with the aim of collecting data about past experiences on transition from childhood. According to Cohen, Manion, and Morrison (2007), this method is aimed at individuals who at a certain point of achievement in life remember events from the past. These data are obtained at an individual or a micro level and on a retrospective analysis of the past in the selected sample. Cohen, Manion, and Morrison (2007) highlight three important advantages of this method, namely a clear focus, detection of causal relationships and the possibility of collecting data that are not subject to the experimental method. Its shortcomings can be deficiencies in memorized information (forgotten or suppressed), interpretations of one's own behaviour that does not coincide with events, the possibility of the end state being different and unclear, with perceived consequences as a possible cause and vice versa, and the impossibility of their rejection or confirmation. However, on the other hand, such research is crucial because of the fact that it is the only way certain data such as childhood experiences can be collected from people. Previous research has indicated the usefulness of a retrospective research method based on which significant data on educators' experiences and attitudes are obtained, which have a significant effect on their educational work (Tatalović Vorkapić and Knapić 2015; Swindle et al. 2018).

\section{Research Aim, Problems and Hypotheses}

Given the importance of experienced and perceived transitions during childhood, both in general and with educators in relation to their implicit pedagogy, the importance of studying transitional objects, and given the evident lack of similar research in this area, the aim of this paper was to research the perception of students and early childhood educators regarding childhood transition experiences and transitional objects. Given the previously described theoretical model, the prevalence of positive experiences of personal transition periods of students and educators during childhood is expected, as well as the reporting of soft toys as the most common transitional objects. 


\section{Methods}

\section{Participants}

A research was conducted on a non-random sample of $N=287$ preservice teachers and early childhood educators ( 5 men and 283 women). The average age of the respondents was $M=30.11$ years ( $S D=11.38$ ), ranging from 18 to 64 years of age. Of the total sample, 175 participants were employed and their average length of service was $M=7.13$ years $(S D=10.50$ ), ranging from no working experience at all to 41 years of service. Out of two subsamples participating in the research, the first subsample consisted of 137 early childhood educators from eight kindergartens from the Primorje-Gorski Ko$\operatorname{tar}$ County.

The second subsample consisted of 150 undergraduate and graduate students enrolled in the study programme of Early and Preschool Care and Education at the Faculty of Teacher Education in Rijeka, which included four generations of students: 44 in the first, 31 in the second, 34 in the third, and 28 in the fourth study year.

\section{Measure}

A short survey developed for the purpose of this research was applied in the research. It consisted of a total of 6 questions: three related to sociodemographic data: age, gender and length of service, and three to open-ended questions related to childhood transition experiences and transitional objects, as well as the feelings with which respondents mostly associate the comfort provided by a transitional object. The last three questions were processed by a qualitative analysis, and they were:

1. Please describe your first transition period and adjustment in life: at what age approximately; what situation; who was and who was not your support then; if it was kindergarten and how you experienced it, if it was school and how you experienced it; what did you learn then; how did you feel; if you had your own transitional object, what was it; what were the educators like towards you; and what your relationship with your parents was like. Write down everything you remember about that situation;

2. Please state what your transitional object was, and briefly describe it;

3. Choose which sensation is mostly associated with the comfort provided to you by your transitional object: smell, taste, touch, sight and hearing. 


\section{Procedure}

Prior to the implementation of the research, a formal letter requesting cooperation in the research, which is part of the university scientific project Children's Well-Being in Transition Periods: The Empirical Validation of the Ecological-Dynamic Model, was sent to appropriately selected kindergartens in Primorje-Gorje County. A student who had the task of writing a master thesis at the Faculty of Teacher Education also participated in collecting data for this study. After obtaining the necessary consents from the contacted kindergartens, the educators who participated in the research were contacted to fill out a survey. In addition to the first subsample, the division of surveys for the second subsample of students was approached at the same time, and the professors of individual study years were contacted. Besides getting the survey, the participants received an insight into the official letter which contained the contacts of the researchers, the purpose of the research and the method of obtaining feedback. The participants were provided with anonymity, and participation was voluntary. Completing the survey took about 15 minutes. Collected data were analysed with thematic analysis (Braun and Clarke 2006; 2013). It can be used within scientific research as a quantitative or qualitative method, depending on how the goal of the research is defined (Milas 2005). Taking into account the aim of this research, thematic analysis was applied in both ways: qualitative by defining key categories, and quantitative by determining the frequency of responses within individual thematic categories. This method is often used in scientific research because it allows the analysis of secondary data on previous behaviours and communication, with the aim of determining the frequency of certain, specific units of analysis (e.g. as in this category research) in the collected qualitative data. It also provides an objective, quantitative and qualitative description of the content according to predefined criteria, which are listed at the beginning of each research question.

\section{Results and Discussion}

The results showed that 263 participants gave an answer, while 24 participants did not give an answer, to the first question related to the description of the experiences of the first transitions during childhood. A detailed qualitative data analysis resulted in the definition of 9 response categories: Memories about childhood transitions; The transition experience is described as ...; The adjustment in nursery or kindergarten or school was ...; The first transition during childhood was to ...; Did you have a transitional object; The feelings experienced during the transition were ...; The memories on educators 
were ...; The relationship with my parents was ... For a better understanding of the determined subcategories within these nine categories and their frequencies, the results are shown in two tables. Thus, table 1 presents the first five categories and their subcategories with frequencies of transition experiences during childhood, while table 2 presents the other four categories with their subcategories and frequencies. Looking at table 1, it can be seen that, of the total number of participants who gave an answer in the domain of remembering the first transitions during childhood, the largest number of them remembered their first transition. The participants who remembered the transitions did not necessarily describe their experiences entirely from their own memory, i.e. some described them based on the narrations of people close to them. Moreover, some participants got a general impression of the entire adjustment based solely on the retelling of events by their parents, yet the vast majority of participants retell events and experiences based on their own memories. Furthermore, based on the participants' responses related to the description of their experiences, the responses were divided into three groups: positive, mixed, and negative experiences. Most of the participants described their experience of adjustment as a positive experience, which confirmed the hypothesis. They mentioned the positive emotions that appeared during that experience, the support they received from their environment, but also the positive atmosphere that greeted them in the new experience. An example of a positive experience from the collected data: 'At the age of three, I started kindergarten, until then I was cared for by my dad, who did not work. The first day of kindergarten I stayed asleep, I didn't want to go home (according to the adaptation notes from kindergarten). I felt cheerful, relaxed, it was nice. The educators were the best. I did not have a transitional object. I made friends right away, mostly my kindergarten was a great place from day one!'

A small number of participants described their experience as mixed, in terms of citing both positive and negative aspects of transition. During the adaptation, the participants encountered difficulties, but at the same time they had the support of the environment, which facilitated the overall situation. An example of a mixed experience is: 'My first transition period was when I turned 5 and when I started kindergarten. The biggest support in that period were my teachers in the kindergarten, the new friends I made then and my mother's promise that she would come back for me after work. It was a pretty stressful time because it was hard for me to be separated from my parents. I think I started kindergarten too late and that made the transition situation more difficult. I did not have a transitional object.' The participants 
Table 1 Determined Five Categories, Subcategories and Frequencies of Transition during Childhood

\begin{tabular}{llr}
\hline Category & Subcategory & $F$ \\
\hline Memories about childhood transitions & Have a memory of transition & 212 \\
& Don't have a memory of transition & 25 \\
& No answer & 50 \\
\hline The experience is described as ... & Positive & 132 \\
& Mixed & 16 \\
& Negative & 37 \\
& No answer & 101 \\
\hline The adjustment in nursery or kindergarten & Easy & 123 \\
or school was... & Moderate & 45 \\
& Hard & 38 \\
& No answer & 81 \\
\hline What was the first transition to during & To nursery & 12 \\
childhood? & To kindergarten & 116 \\
& To preschool & 13 \\
& To primary school & 65 \\
& Something else & 25 \\
& No answer & 56 \\
\hline The support was provided by ... & Parents & 107 \\
& Educators & 50 \\
& Family members & 48 \\
\hline & Friends & 22 \\
& Nobody & 31 \\
& No answer & \\
& & 48 \\
& & \\
& & \\
& &
\end{tabular}

who described their adaptation experience as negative cited many negative emotions related to the described experience, while not receiving the necessary support from their environment, as can be seen from this example: 'My first transition was from home to kindergarten. It was very stressful, the educators were not professional. They did not encourage other children to communicate with me but further humiliated me in front of the rest of the group. At one point I read a picture book locked up alone in a group because I was "naughty." After three days in kindergarten, I jumped over the fence and then my mother decided for me to leave that kindergarten. Later, I enrolled in a new kindergarten in the city, where the educators were wonderful, like the whole experience.'

Furthermore, according to the descriptions of the adjustment process, the 
participants' answers were divided into three categories: easy, medium and difficult. Most participants described their adjustment process as easy, which was to be expected (Tatalović Vorkapić, Pregelj-Čargonja, and Mihić 2015; Tatalović Vorkapić 2020; Visković and Višnjić-Jeftić 2019). The adjustment went relatively quickly, without any issues, with the usual reactions and with the support of their environment. The participants associated such experiences with a positive context and an example of one such experience is: 'My transition period began in the 3 rd year when I started kindergarten. Before going to kindergarten, my grandmother looked after me. Everyone supported me and there were no excessive problems with me. They told me that I did not cry but that I made new friends on the first day. I still remember those friends today, Virginia and Paolo. Apart from my parents, I was also supported by kindergarten teachers ....' The participants whose descriptions of transition periods were classified as moderate adjustment experienced a longer duration of adjustment and experiencing specific reactions, as seen in the example: 'I only remember how I had a very difficult adjustment to kindergarten and cried constantly for the first two weeks. After that, with the help of the educator, I calmed down and slowly started to get used to kindergarten. I didn't have a transitional object.' Participants who described a difficult adjustment cited their significantly prolonged duration and extreme reactions, with insufficient environmental support. An example of a difficult adjustment from the participants' answers is: 'Going to kindergarten was a difficult transition period. Very difficult adjustment to kindergarten. Every day I experienced crying and walking along the glass hall after my grandmother left me in the kindergarten, which did not stop for months.' Children can experience the first separations and transition periods at different periods of life by moving to different institutions, so these responses of the participants are divided into five subcategories. Most participants stated that they experienced the first transition by enrolling in kindergarten, and significantly less by enrolling in a nursery. If the participants did not attend kindergarten, the most common first transition was to primary school, and a significantly smaller number of them mentioned their first transition to preschool. The participants also mentioned other answers such as being cared for by other family members or a personal nanny, moving to another city/country, enrolling in college, a new job and the like. The support of the close environment is extremely important for any transition (Tatalović Vorkapić 2020; Tatalović Vorkapić and LoCasaleCrouch 2021; Visković and Višnjić-Jeftić 2019), so the participants stated who provided them with the necessary support at that time. They often cited several different responses, and the number of repetitions of each response was 
Table 2 Determined Next Four Categories, Subcategories and Frequencies of Transition during Childhood

\begin{tabular}{llr}
\hline Category & Subcategory & $F$ \\
\hline Did you have a transitional object? & Yes & 65 \\
& No & 59 \\
\hline What were the experienced feelings during transition? & No answer & 163 \\
\hline What was the memory of educators? & Mixed & 77 \\
& Negative & 54 \\
& No answer & 41 \\
& Positive & 115 \\
\hline What was the relationship with parents? & Mixed & 79 \\
& Negative & 14 \\
& No answer & 26 \\
& Excellent & 125 \\
\hline
\end{tabular}

shown, again divided into subcategories. Separately by subcategories, parents were most often listed followed by educators and teachers. In addition to the parents, the significant others during the transition were other family members: siblings, grandparents, but also other family relatives. Moreover, the participants emphasized the importance of friends' support in transition situations, while a small number of those who did not have the support of people from their environment were identified.

Table 2, which shows the remaining four categories of responses, as well as their subcategories and frequencies, shows that a certain, larger number of participants stated that they had a transitional object, while a smaller number did not. When describing the transition periods, the participants described the positive, mixed and negative feelings they experienced. A number of them described positive emotions: security, relaxation, happiness, support, comfort, joy and the like, and this is one example: 'My first transition period was from the family home to the 1st grade of primary school. My parents were supportive of me and I adjusted quickly when I came to the new group. The teacher developed a good sense of security and everybody in her class felt relaxed and easily adapted to the new situation.'

Furthermore, a number of participants described mixed emotions, such as: sadness, fear, and resentment, but at the same time support, security, and 
habituation. An example of a mixed experience is: 'The period of transition from kindergarten to school (7 years of age). My parents were the biggest support because school was something completely new for me and at first I felt quite uncomfortable. With the support of my parents, I was supported by the teacher and I felt more comfortable creating a good relationship with other students in the class.' A certain number of participants stated dominant negative emotions during the first transitions, which mainly included sadness, loneliness, anger, frustration, fear, awe, rejection, non-acceptance, misunderstanding, withdrawal, etc., and an example of one description is the following: 'The first transition was when I started kindergarten at 4 years of age. Since my mother was on maternity leave and I moved from the nursery to a new unknown institution, I cried by the window every morning and expected my parents to come and pick me up. The first meeting with the kindergarten was bad for me and since I couldn't adjust, I dropped out and moved to another one where it was much better, but I never developed a connection with the educators and I wasn't really looking forward to going to kindergarten. My transitional object was a teddy bear, but I never took it to kindergarten.'

When describing memories of educators, the participants' responses were categorized as: positive, mixed, and negative memories. The participants who described their memories of educators as positive were the most numerous, emphasizing their goodness, kindness, patience, compassion, competence and the like. An example of a positive memory is: 'The first transition was when I was about three years old and when I started kindergarten. My parents, educators and family supported me. I did not have a transitional object. The educators were old, gentle and kind.' A significantly smaller number of participants who had mixed experiences described different aspects of the same situation, for example: 'I don't remember exactly, but I know from stories that I started kindergarten at the age of 3 and cried and dove to the floor because I didn't want to go to kindergarten. When someone came for me I wouldn't want to go home. I would also refuse and throw away my sneakers. That was when my parents divorced, so maybe my behaviour was related to that, too. The educator was a classical traditional educator and quite strict, but I still loved her'. The participants also described their negative memories of educators, stating a lack of their competencies, favouring certain children, not providing support, not establishing emotional connection and the like. An example of a negative memory is: 'My transition period from home to kindergarten, I did not tolerate it well and I was not able to spend all the time there. So, I would spend only a few hours in kindergarten and my dad 
would usually pick me up before lunch. The educators did not give me much support and understanding and I remember one educator was quite cold. I was left with such a bad memory.' Finally, the participants also described their relationship with parents, which is also an important segment of each transition, and their responses were divided into three categories: excellent, good, and poor. The participants who had an excellent relationship with their parents during transitions stated that they had their support in the process, for example: 'My first transition period was from home to primary school. Considering that I did not attend kindergarten, it took me a little longer to adjust and my parents were a great support. They had a lot of patience and they were calm, which helped me a lot.' Furthermore, the participants described the good relationship with their parents in a positive light, but still did not state their support in difficult times: 'At the age of six, I experienced my first transition from home to the first grade of primary school. I was never in favour of change, and going to an unknown place with unknown people until an unknown time was scary and stressful, so school always made me uncomfortable. The teachers were friendly and kind; I didn't have a transitional object. The relationship with my parents was good.' Finally, the participants also described bad relationships with their parents during transition: 'When I came to Croatia, I immediately went to a kindergarten in Zagreb and changed it twice. Making friendships never mattered so I was often a new kid and without friends. As I had no friends, Christopher, my toy figure, was a help to me and provided me with security and comfort. I felt mostly lonely and misunderstood, the relationship with my parents was bad and minimal. The educators were fine, I remember educator Nina who was my support and always helped me and taught me to tie my sneakers.'

Furthermore, the qualitative data analysis of the second question from the survey related to the transitional object determined the results on categories, descriptions and frequencies shown in table 3. The results show that most participants mentioned a soft toy or stuffed animal as their most common transitional object, which is also determined in the previous research literature (Gulerce 1991; Wilson and Robinson 2002; Fortuna et al. 2014). After that, most of the participants mentioned transitional objects which could also be found in the relevant literature: blankets, pillows, diapers, cloth and gauze. A common feature connects all of the above transitional objects, which is softness. This characteristic is closely related to the sense of touch, which the participants also mentioned as the most significant sense that they associate with transitional objects. The participants also stated that they do not remember, do not know, or did not have transitional objects. In addition, they 
Table 3 Determined Categories of Transitional Objects, Their Descriptions and Frequencies

\begin{tabular}{llr}
\hline Category & Description & $F$ \\
\hline Soft toys & $\begin{array}{l}\text { Teddy bear, rabbit, elephant, mouse, monkey, frog, duck, } \\
\text { koala, chicken, clown, griffon vulture, pig, tiger, dog, cat, } \\
\text { lamb, panda, lion }\end{array}$ & 54 \\
\hline Dolls & $\begin{array}{l}\text { Doll (speaks, sleeps, cries) which is: rag, stuffed, plastic, } \\
\text { bald, porcelain, small, big, shaggy }\end{array}$ & 13 \\
\hline $\begin{array}{l}\text { Blankets, pillows, diapers, } \\
\text { cloth, gauze }\end{array}$ & $\begin{array}{l}\text { Canvas, small, soft, white, silk trim, home scent, pattern, } \\
\text { wool }\end{array}$ & 33 \\
\hline Pacifiers, bottles & Various shapes and colours & 6 \\
\hline Something else & $\begin{array}{l}\text { Ball (1), bag (1), colouring book (1), figurine (2), pen- } \\
\text { dant (1), rubber toy (1) }\end{array}$ & 7 \\
\hline I don't know, I don't remem- & I don't know (1), I don't remember (6), I didn't have \\
ber, I didn't have one & one (10) & 17 \\
\hline
\end{tabular}

list dolls, a pacifier and bottles and similar as transitional objects. The use of pacifiers and bottles as a transitional object is not surprising in the least because children of an early age reduce stress levels by oral stimulation and thus facilitate separation from the mother, and this kind of stimulation is one of the most common (Gulerce 1991). In addition to enumeration, the participants were also tasked with describing their friendly and loved transitional objects. The participants describe the stuffed animals through the character they represented, and the vast majority of them were animals. Through the sense of touch, materials and softness the participants described the category of transitional object that consists of blankets, pillows, diapers, cloths and gauze. They also described the dolls according to the material from which they are made (plastic, rag, porcelain) and according to the appearance that has remained in their memory. Their descriptions can most often be associated with two senses, namely touch and sight.

The last question referred to the sensations associated with the pleasures and comfort associated with transitional objects, and the participants were able to choose one or a combination of multiple answers, which could be observed in figure 1. Namely, Klarić (2013) in her research stated touch as an important feeling when we talk about transitional objects in children. She also pointed out that children at a later age choose soft items for soothing purposes at times when they go to bed. Such objects can be hugged, held and caressed, and at the same time they remind them of their mother (Gulerce 1991). In this study, most participants associated their pleasure related to the transitional object with the sense of touch as expected, followed by smell, sight, and taste, while none of the subjects associated comfort with 


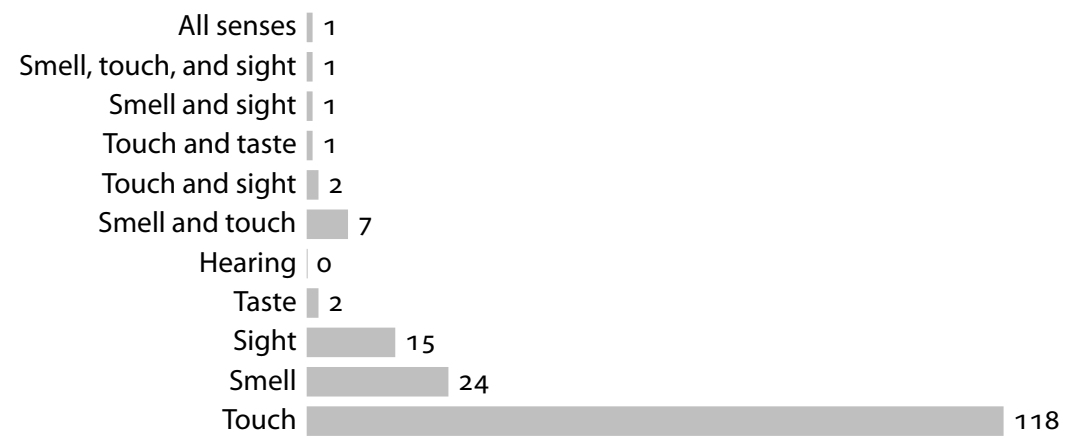

Figure 1 Frequencies of Reported Experienced Senses to Which the Participants Attached the Comfort Provided by the Transitional Object

the sense of hearing. Of the possible combinations, most participants chose a combination of sense of smell and touch. It is about the feelings through which a child experiences comfort and security, and thus the strengthening of their attachment, which is extremely important in new, challenging situations (Wilson and Robinson 2002).

\section{Conclusion}

In relation to the set goal of this study related to the educators' and students' perception of their childhood transitions and transitional objects, different experiences, with the prevalence of positive transition experiences, were identified, as well as the expected type of transitional objects used in childhood. Although a non-random sample was used in the research and the participants did not provide answers to all sub-questions, this is a rare research in Croatia, which significantly empowers its contribution to this area. The educator is a very important person in the overall development of the child, so (s)he presents a significant model regarding appropriate skills, abilities, personality traits, and attitudes. It is certainly necessary to show enthusiasm in work, motivation and love for working with children, as well as nurture and improve their pedagogical-psychological competencies that can effectively address the challenges of working with children and their individual and specific needs at any time. Within the relevant competencies of a modern educator, it is extremely important to achieve one's own well-being, which has been shown to be significantly correlated with the well-being of children in the educational group. It is crucial to be aware of one's own attitudes, which are shaped by early experiences, and to critically approach their effect on working with children. Being aware of the size of the impact of educators' 
actions on the development of young and preschool children in everyday educational work, and bearing in mind the sensitivity of transition periods for each child, the importance of such impact is further enhanced by children's well-being and thus the need for continuous research and improvement of quality educational practice.

\section{Acknowledgements}

This paper has been supported in part by the University of Rijeka under the project number uniri-drustv-18-11, 'Children's Well-Being in Transition Periods: The Empirical Validation of Ecological-Dynamic Model.'

\section{References}

Bachar, E., L. Canetti, E. Galiee-Weisstub, A. Kaplan-DeNour, and A. Y. Shalev. 1998. 'Childhood vs. Adolescence Transitional Object Attachment, and Its Relation to Mental Health and Parental Bonding.' Child Psychiatry and Human Development 28 (3): 149-167.

Ben-Arieh, A., F. Casas, I. Frønes, and J. E. Korbin. 2014. Handbook of Child Well-Being: Theories, Methods and Policies in Global Perspective. Dordrecht: Springer.

Braun, V., and V. Clarke. 2006. 'Using Thematic Analysis in Psychology.' Qualitative Research in Psychology 3 (2): 77-101.

—. 2013 Successful Qualitative Research:A Practical Guide for Beginners. London: Sage.

Bronfenbrenner, U. 1979. The Ecology of Human Development: Experiments by Nature and Design. Cambridge, MA: Harvard University Press.

Cohen, L., L. Manion, and K. Morrison. 2007. Metode istraživanja u obrazovanju. Zagreb: Naklada Slap.

Fabian, H., and A. Dunlop. 2002. 'Introduction.' In Transitions in the Early Years: Debating Continuity and Progression for Children in Early Education, edited by H. Fabian and A.-W. Dunlop, 1-7. London: Routledge.

Fortuna, K., L. Baor, S. Israel, A. Abadi, and A. Knafo. 2014. 'Attachment to Inanimate Objects and Early Childcare: A Twin Study.' Frontiers in Psychology: Personality and Social Psychology 5: 486. https://doi.org/10.3389/fpsyg.2014 .00486 .

Gulerce, A. 1991. 'Transitional Objects: A Reconsideration of the Phenomenon.' Journal of Social Behavior and Personality 6 (6): 187-208.

Klarić, V. 2013. 'Značaj prijelaznih fenomena u razvoju djeteta.' Medica Jadertina 43 (4): 201-206.

Mahler, M. S. 1972. 'On the First Three Subphases of the Separation-Individuation Process.' International Journal of Psychoanalysis 53 (3): 333-338.

Mašković, T., D. Drožđan, M. Sokač, and M. Josić. 2018. Od jaslica do škole: vodič za lakši proces prilagodbe na jaslice, vrtić i školu. Zagreb: Printera grupa. 
Mihić, I. 2016. Vrtić kao sigurna baza: adaptacija dece nakon Jaslenog uzrasta. Novi Sad: Filozofski fakultet.

Milas, G. 2005. Istraživačke metode u psihologiji i drugim društvenim znanostima. Jastrebarsko: Naklada Slap.

Pianta, R. C., and M. J. Cox. 1999. The Transition to Kindergarten. Baltimore, MD: Paul H. Brookes.

Rimm-Kaufman, S. E., and R. C. Pianta. 2000. 'An Ecological Perspective on the Transition to Kindergarten: A Theoretical Framework to Guide Empirical Reserch.' Journal of Applied Developmental Psychology 21 (5): 491-551.

Swindle, T. M., W. L. Ward, P. Bokony, and L. Whiteside-Mansell. 2018. 'A CrossSectional Study of Early Childhood Educators' Childhood and Current Food Insecurity and Dietary Intake.' Journal of Hunger \& Environmental Nutrition 13 (1): 40-54.

Tatalović Vorkapić, S. 2012. 'The Significance of Preschool Teacher's Personalitiy in Early Childhood Education: Analysis of Eyesenck's and Big Five Dimensions of Personality.' International Journal of Psychology and Behavioral Sciences 2 (2): 28-37.

- 2019a. 'Children's Well-Being during Transition Periods in Croatia: The Proposal of Empirical Validation of Ecological-Dynamic Model.' In INTED 2019 Proceedings, edited by L. Gómez Chova, A. López Martínez, and I. Candel Torres, 265-276. Valencia: IATED.

_. 2019b. 'Podrška socijalno-emocionalnoj dobrobiti djece u Hrvatskoj: prikaz tri znanstveno-stručna projekta.' In EDUVision 2019: sodobni pristopi poučevanja prihajajočih generacij, edited by M. Orel in S. Jurjevčič, 69-83. Ljubljana: EDUvision.

- 2019c. 'Socio-emocionalna dobrobit i otpornost djece rane i predškolske dobi: kako omogućiti da djeca (p)ostanu dobro?' Dijete, vrtić, obitelj 89:2-6.

-2020. Psihologija privrženosti i prilagodba u dječjemu vrtiću - psihologija dobrobiti djece. Vol. 1. Rijeka: Sveučilište u Rijeci.

Tatalović Vorkapić, S., and V. Katić. 2019a. 'The Challenges of Transition and Adaptation among Early and Preschool Aged Children from the Early Childhood Educators' Perspective.' In Requirements and Approaches for Contemporary Teacher Training, edited by M. Županić Benić, O. Holz, and M. Michielsen, 199-212. Wien and Zürich: Lit.

— 2019b. 'Kompetencije budućih odgajatelja iz područja prijelaza i prilagodbe: analiza studijskih programa i implikacije za promjene.' In Prozor u svijet obrazovanja, nauke i mladih: zbornik radova, edited by S. Nesimović and E. Mešanović-Meša, 309-324. Sarajevo: Pedagoški fakultet u Sarajevu.

Tatalović Vorkapić, S., and I. Knapić. 2015. 'Čega smo se bojali kad smo bili djeca? Važnost ranih iskustava budućih odgajatelja za njihov rad s djecom.' Metodički obzori 10 (1): 62-76. 
Tatalović Vorkapić, S., and J. LoCasale-Crouch. 2021. Supporting Children's Wellbeing during Early Childhood Transition to School. Hershey, PA: IGI Global.

Tatalović Vorkapić, S., Ž. Pregelj-Čargonja, and I. Mihić. 2015. 'Validacija ljestvice za procjenu privrženosti djece rane dobi u fazi prilagodbe na jaslice.' Hrvatska revija za rehabilitacijska istraživanja 51 (2): 1-15.

Visković, I., and A. Višnjić-Jevtić. 2019. Je li važnije putovati ili stići!? Prijelazi djece rane i predškolske dobi iz obitelji u odgojno-obrazovne institucije. Zagreb: Alfa.

Wilson, A., and N. M. T. Robinson. 2002. 'Transitional Objects and Transitional Phenomena.' In Encyclopedia of Psychotherapy 2, edited by M. Hersen and W. H. Sledge, 861-866. Amsterdam: Elsevier.

Winnicott, D. W. 1953. 'Transitional Objects and Transitional Phenomena.' International Journal of Psycho-Analysis 34:89-97.

\section{Retrospektivna študija o prehodih in prehodnih objektih}

Ker sodobne študije jasno dokazujejo pomemben vpliv zgodnjih otroških izkušenj vzgojiteljev na njihovo delo z otroki, jih je pomembno nenehno raziskovati. Nekatere od teh izkušenj so povezane $z$ različnimi prehodi $v$ otroštvu, $s$ prilagoditvami v jaslih ali vrtcu ter $z$ vlogo in uporabo prehodnih predmetov $v$ otroštvu. Zato je bil cilj te študije raziskati, kako vzgojitelji v zgodnjem otroštvu dojemajo svoje osebne prehode in prehodne predmete v otroštvu. Zaznavanje osebnih prehodnih obdobij je bilo preučeno $z$ anketo, ki je bila oblikovana za namen te raziskave, retrospektivna metoda pa je bila uporabljena na vzorcu 287 vzgojiteljev s Hrvaške. Ugotovljena je bila razširjenost pozitivnih izkušenj pri osebnih otroških prehodih. Kot najpogostejši prehodni predmeti so navedene mehke igrače. Ugotovitve te študije kažejo na pomen preučevanja procesa prehoda in vloge prehodnih predmetov.

Ključne besede: učitelji v zgodnjem otroštvu, retrospektiva, učenci, prehod, prehodni predmeti 